\title{
New method for intraoperatory occlusal restauration in mandibular angle fractures treatment using two modified reduction forceps
}

\author{
José Lineu Pereira OGOSHI ${ }^{1}$ \\ Rogerio Henrique BERARDI ${ }^{2}$ \\ Denis ZANGRANDO ${ }^{3}$ \\ Fernando Kendi HORIKAWA 4 \\ Susana MORIMOTO 5 \\ Elio Hitoshi SHINOHARA ${ }^{6}$
}

${ }^{I}$ DDS - OMF Surgeon. MSc Student. Post graduate Program. Dental School-Ibirapuera University-Unib. Sao Paulo, Brazil

${ }^{2}$ DDS - Dental implants specialist. MSc Student. Post graduate Program. Dental School-Ibirapuera University-Unib. Sao Paulo, Brazil

${ }^{3}$ DDS - Assistant Surgeon. Department of Oral and Maxillofacial Surgery. Hospital Regional de Osasco SUS/SP. MSc Student-Post Graduate Program. FOB-USP

${ }^{4}$ DDS, PhD - Associate Surgeon. Department of Oral and Maxillofacial Surgery. Hospital Regional de Osasco SUS/SP. Osasco, Brazil ${ }^{5}$ DDS, PhD - Post graduate Program. Dental School-Ibirapuera University-Unib. Sao Paulo, Brazil

${ }^{6}$ DDS, PhD - Assistant Surgeon. Department of Oral and Maxillofacial Surgery. Hospital Regional de Osasco SUS/SP São Paulo(SP), Brazil

\begin{abstract}
The treatment of mandibular angle fractures presents several possibilities for fixation methods and surgical approaches which can be intraoral or can be accessed through the skin. An important point would be intraoperative occlusal restoration. We present a method that replaces the traditional form using an erich bar and which, in our view, is a fast and effective method for intraoperative occlusal restoration.

Descriptors: Inter Maxillary Fixation (IMF); Occlusion; Arch Bar Fixation.
\end{abstract}

\section{INTRODUCTION}

Intraoperative occlusal restoration is an important step in the surgical treatment of fractures of the gnathic bones. Traditionally this occlusal restauration is done with the use of Erich Bars, but recently other methods have emerged that are faster and safer for the surgeon ${ }^{1,2}$. Mandibular angle fractures are frequent and when open surgery for their reduction and fixation is indicated, they can be accessed intra or extra orally.

\section{TECHNIQUE}

Occlusion is maintained by manual pressure. We use two modified forceps ${ }^{3}$ that are positioned in the interproximal space of upper and lower bicuspids bilaterally (Figure 1). Once the occlusal restauration is achieved, the fracture is accessed and the entire treatment is completed in a conventional manner. We recommend the use of bicuspids or molars, as they usually have good periodontal implantation and it is possible to check the key occlusion in the canines and molars.

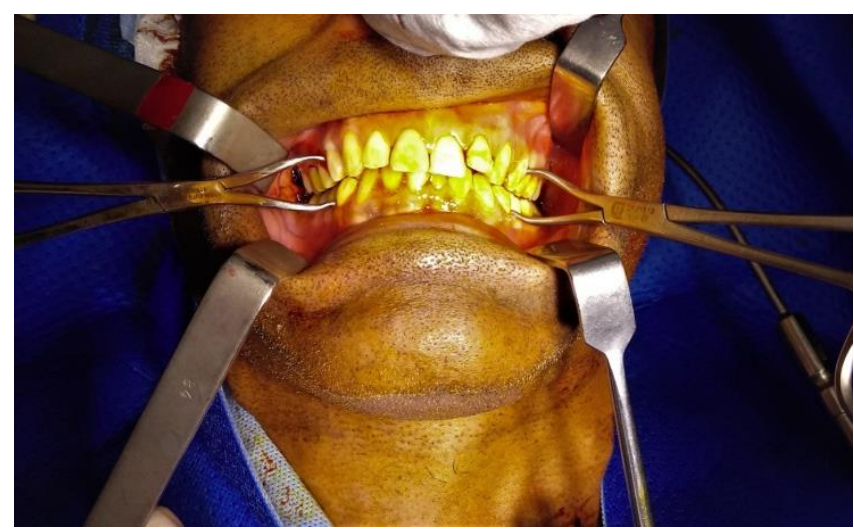

Figure 1: Two modified reduction forceps positioned in the interproximal space in bicuspids bilaterally (The patient consent was obtained.)

\section{DISCUSSION}

This technique, we indicate when a mandibular angle fracture is the surgical objective. The start is made with manual reduction until the forceps are adjusted. We always recommend detect a neutral condylar position in the articular fossa. If for any reason mainly lack of teeth for occlusal checking, we recommend the traditional technique using erich bar. In cases with fractures in the body and other dentate areas, we ever use the Erich bar because in our understanding that the main advantage is it neutralizes the tension zone. A clinical trial is now recommended to check the effectiveness of this technique.

\section{REFERENCES}

1. Johnson AW. Dental occlusion ties: A rapid, safe, and non-invasive maxillo-mandibular fixation technology. Laryngoscope Investig Otolaryngol. 2017;2(4):178-83.

2. Abbasi AJ, Parvin M. New method of arch bar fixation. Br J Oral Maxillofac Surg. 2017; 55(6):631-32.

3. Shinohara EH, Mitsuda ST, Miyagusko JM, Horikawa FK. Mandibular fracture reduction without intraoperative intermaxillary fixation: a technique using two modified reduction forceps. J Contemp Dent Pract. 2006;7(1):150-56. 


\section{CONFLICTS OF INTERESTS}

The authors declare no conflicts of interests.

\section{CORRESPONDING AUTHOR}

\section{Elio H Shinohara DDS, PhD.}

Dept Oral and Maxillofac Surg

Hospital Regional de Osasco SUS/SP

Rua Ari Barroso, 355. Presidente Altino

06216-902 Osasco (SP), Brasil

Email: elioshinohara@yahoo.com.br

Received 09/06/2020

Accepted 19/08/2020 